\title{
Do parasitoids reduce cereal losses? Estimating the impact of parasitoids on stem borer pest infestation and maize yield
}

\author{
Esther Adhiambo Abonyo1,2, George Otieno Ongámo1,2, Gideon Nyamasyo', Catherine Lukhoba', \\ Gerphas Ogola², Zoul Midingoyi³, Hippolyte Affognon33, Bruno Le Ru'2,4 \\ ${ }^{1}$ College of Biological and Physical Sciences, University of Nairobi, P. O. Box, 30197, Nairobi, Kenya \\ 2International Centre of Insect Physiology and Ecology, icipe, P. O. Box 30772-00100, Nairobi, Kenya \\ 3 International Crops Research Institute for the Semi-Arid Tropics, BP 320, Bamako, Mali \\ 4UMR IRD 247, EGCE, Evolution, Génomes, Comportement et Ecologie, CNRS, 91198 - Gif-sur-Yvette, France and \\ Université de Paris-Sud, 91405 - Orsay, France. \\ Corresponding author: Esther Adhiambo Abonyo E-mail address: e_abonyo@yahoo.com
}

Original submitted in on $13^{\text {th }}$ February 2019. Published online at www.m.elewa.org/journals/ on $30^{\text {th }}$ April 2019 https://dx.doi.org/10.4314/jab.v136i1.8

\begin{abstract}
Chilo partellus (spotted stem borer) is an economically important stem borer pest in Eastern Africa causing high yield losses in maize and sorghum. The larval endoparasitoid, Cotesia flavipes (parasitic wasp) was released in Kenya to manage $C$. partellus and post release studies showed it had established and stem borer parasitism was steadily increasing. Despite the rise in parasitism, doubts on whether parasitoids can effectively reduce stem borer populations have been raised.

Objective: This study was carried out to estimate the impact of $C$. flavipes on stem borer infestation and the resultant effect on maize yield in Kenya.

Methodology and results: Using insecticidal check method, selective insecticides were used to exclude stem borer pests and natural enemies in Treatments $A$ and $B$ respectively with controls designated as Treatment $C$. Results revealed significant differences in stem borer infestation $\left(F_{2,9}=5.835 ; p<0.05\right)$ and parasitism $\left(F_{2,9}=91.97 ; p<0.0001\right)$ among the three treatments. Significantly higher infestation was recorded in treatment $B(2.0 \pm 0.2 \%)$ compared to $A(0.5 \pm 0.3 \%)$ and $C(1.5 \pm 0.4 \%)$. Parasitism was significantly higher in treatment $C(23.5 \pm 6.8 \%)$ compared to $A(0.0 \pm 0.0 \%)$ and $B(0.3 \pm 0.1 \%)$. However, there was no significant difference in yield among treatments showing that parasitoid action did not translate into changes in yield.

Conclusions and application of findings: The parasitoid C. flavipes has made an important contribution towards suppressing stem borer population. This was shown by high infestation recorded in treatment $B$ which was as a result of partial elimination of parasitoids. This deduction was further supported by the results which showed that pest exclusion using chemicals did not have a significant difference from parasitoid action as shown by insignificant difference in infestation between treatment $\mathrm{A}$ and $\mathrm{C}$ fields. Percentage infestation and parasitism results obtained from this study thus provide quantitative data on the impact of $C$. flavipes. Release of $C$. flavipes can therefore be done in other areas both within and beyond the country's borders where $C$. partellus is still a problem. However, since reduced infestation and increased parasitism did not translate into yield increase, more suppressive effect may be achieved if the
\end{abstract}


pest's multiple developmental stages are targeted, most especially before it reaches the destructive larval stage. There is need to carry out further research on C. partellus' egg parasitoids. Optimum yield may then be realized.

Key words: Classical biological control; Chilo partellus ; Cotesia flavipes; parasitism; insecticidal check technique; Kenya

\section{INTRODUCTION}

Parasitoids have been used in different agroecosystems as biological control agents for many years (Rodriguez and Hawkins, 2000; Gullan and Cranston, 2005; Sanda and Sunusi, 2014). In classical biological control (CBC), parasitoids are released in areas where previously harmless insects have become pests after accidental introduction outside their native range (Greathead, 1990; DeBach and Rosen, 1991; Mohyuddin, 1991). Chilo partellus (Swinhoe) (Lepidoptera: Crambidae) is one of the exotic insects that became an important pest in Eastern and Southern Africa (ESA). Accidentally introduced in the 1930's from Asia (Tams, 1932), C. partellus infestation has resulted in yield losses estimated at $73 \%$ in maize and $80-100 \%$ in sorghum (Seshu Reddy, 1983; Reddy and Walker, 1990; Kfir, 1994). As a result of these losses, C. partellus has been a target of various management strategies. The exotic larval parasitoid, Cotesia flavipes Cameron (Hymenoptera, Braconidae), is among biological control agents used in management of $C$. partellus. Two $C$. flavipes releases have been made in East and Southern Africa. In the first release, $C$. flavipes from Rawalpindi, Pakistan, was introduced in Uganda, Kenya and Tanzania by the Commonwealth Institute of Biological Control (CIBC) (now International Institute of Biological Control) between 1968 and 1972. Post release studies showed that the parasitoid did not establish (CIBC, 1968-1972). In the second release, C. flavipes from Sindh region in Pakistan was introduced at three sites in Southern Coastal area of Kenya in 1993 (Overholt et al., 1994). Following the second attempt, surveys revealed that $C$. flavipes had established (Overholt et al., 1994). Subsequent surveys showed that parasitism by $C$. flavipes was rising steadily. This was reflected in initial recoveries made in 1995 and 1996 during which parasitism was estimated at $0.05-3 \%$
(Overholt et al., 1997), 7.1\% in 1997 and 13\% in 1999 (Zhou et al., 2001). Though there was a general increase in parasitism, there are doubts on whether parasitoids can effectively reduce stem borer pest populations below economically damaging levels (Kfir, 1997; Jiang et al., 2006; Kipkoech et al., 2009). These doubts arise due to the fact that there is limited quantitative data on impact of parasitoids on stem borer pest population and the resulting cereal yields (Kfir et al., 2002a; Cugala et al., 2006). The limited quantitative data available on the impact of parasitoids on lepidopteran pest populations is attributed to methodological challenges associated with low densities, mobility of the lepidopteran pests and the endophagous behaviour of the larvae (Kfir, 2004). Due to these challenges, very few studies using insecticidal check method have been undertaken (Kfir, 2002b; Cugala et al., 2006). Insecticidal check method, first described by DeBach (1946), is considered as a good experimental technique for evaluating the efficacy of natural enemies (Jones, 1982, Kenmore et al., 1984; DeBach and Rosen, 1991; Luck et al., 1999). This method has been used to estimate the impact of parasitoids on stem borer pest population in South Africa (Kfir et al., 2002a) and Mozambique (Cugala et al., 2006). Studies were done in regions characterized by stem borer community dominated by Busseola fusca (Fuller) and $C$. partellus respectively. They both observed significantly higher infestation in plots sprayed with a selective insecticide, dimethoate and higher parasitism in unsprayed plots, results they both attributed to partial elimination of parasitoids. These studies were however done on small plots measuring $333 \mathrm{~m}^{2}$ in South Africa and $100 \mathrm{~m}^{2}$ in Mozambique. Results from such small plots may not be effectively used to determine the effect of natural enemies on pest population and the yields 
in large farmers' fields because results are likely to be blurred by movement of natural enemies (van Driesche and Bellows, 1996). Despite limitations associated with aforementioned exclusion experiments (Kfir, 2002b; Cugala et al., 2006), no such study has been undertaken in East Africa, a region where $C$. flavipes was released more than 20 years ago. Extrapolation of results from the

\section{METHODOLOGY}

Description of the study area: The study was carried out in twelve farmers' fields during the short raingrowing season between September 2015 and February, 2016 in Oluch village, Homa-Bay County (Table 1). Oluch village is located in moist mid-altitude AEZ, at an elevation of $1000-1800$ masl between $0^{\circ} 27.949^{\prime}$ to $0^{\circ} 28.001^{\prime} \mathrm{S}$ and $34^{\circ} 33.192^{\prime}$ to $34^{\circ}$ above exclusion experiments in the East African context may not be feasible due to ecological differences. It is on this background that this study was initiated in the moist mid-altitude agroecological zone (AEZ) in Kenya, a region dominated by $C$. partellus with an aim of assessing the impact of $C$. flavipes on stem borer pest population and maize yield.

$33.919^{\prime} \mathrm{E}$. The area is characterised by temperatures ranging from 17 to $32^{\circ} \mathrm{C}$ with bimodal rainfall ranging between 500 and $1000 \mathrm{~mm}$ annually. Bimodal rainfall received in the area allows cultivation of maize in both long and short rainy season.

Table 1: Estimated number of maize plants in different experimental fields

\begin{tabular}{|c|c|c|c|c|}
\hline Treatment & Replication & $\begin{array}{l}\text { Farm size } \\
\text { (Acres) }\end{array}$ & No. of plants & Estimated no. of plants/acre \\
\hline \multirow{4}{*}{ 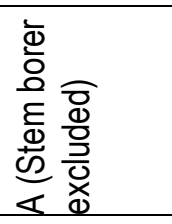 } & I & 0.503 & 6760 & 13439 \\
\hline & $\|$ & 0.178 & 3440 & 19326 \\
\hline & III & 0.600 & 10472 & 17453 \\
\hline & IV & 0.611 & 2808 & 4596 \\
\hline \multirow{5}{*}{ 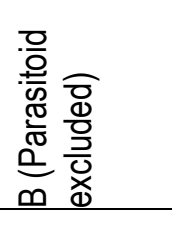 } & I & 0.842 & 10360 & 12304 \\
\hline & $\|$ & 0.687 & 6800 & 9898 \\
\hline & III & 0.438 & 5016 & 11452 \\
\hline & IV & 0.306 & 2200 & 7190 \\
\hline & l & 1.191 & 8580 & 7204 \\
\hline \multirow{3}{*}{$\begin{array}{l}\widehat{\overline{0}} \\
\frac{\underline{\underline{0}}}{0} \\
\frac{0}{0}\end{array}$} & $\|$ & 1.058 & 12470 & 11786 \\
\hline & III & 0.531 & 6630 & 12485 \\
\hline & IV & 0.574 & 2890 & 5034 \\
\hline
\end{tabular}

Study design and insecticide treatment: The twelve fields were purposively selected within a radius of one kilometre so as to limit differences that may arise with respect to ecological characteristics. Selected fields were assigned three different insecticide treatments $(A$, $B$ and $C$ ), and replicated four times. Four maize fields designated for Treatment $A$ were sprayed with stem borer pesticide, Thunder ${ }^{8} 145$ O-TEQ, to exclude stem borers, while fields designated for Treatment $B$ were sprayed with Dimethoate $40 \mathrm{EC}$ to exclude parasitoids. Maize plants in fields designated as Treatment $\mathrm{C}$ were not treated with any insecticide and were thus used as controls. Two millilitres of the stem borer pesticide, Thunder 145 O-TEQ, was mixed with one litre of water and sprayed onto pre-selected fields designated as $A$ to exclude stem borers from maize plants. The two active ingredients in Thunder Imidacloprid and BetaCyfluthrin, act through quick knock-down effect by blocking acetylcholine receptors in insect nerve cells and by keeping sodium channels in membranes of nerve cells open respectively (Bayer Crop Science, 2013). To exclude stem borer parasitoids, two millilitres of the parasitoid insecticide, Dimethoate $40 \mathrm{EC}$, was mixed with one litre of water and sprayed on maize plants in pre-selected fields in Treatment B. Dimethoate $40 \mathrm{EC}$, is a selective organophosphate compound with both systemic and contact action. Dimethoate inhibits the enzyme acetylcholinesterase resulting in nerve 
damage and death (Fukuto, 1990). The first stem borer pesticide spraying was done three weeks after germination of maize plants and three subsequent applications done after every two weeks. The first dimethoate application was done four weeks after germination and two subsequent treatments were done after every two weeks.

Sampling protocol: Sampling for stem borer infestation, densities and parasitism was done once during the $5^{\text {th }}$ week after germination. During each sampling session, all plants in respective treatment fields were inspected for stem borer infestation. The observed number of infested plants were expressed as a percentage of total plants inspected in respective fields. Ten infested plants in each field were sampled and dissected. All stem borer larvae collected after dissection were identified and recorded in three different size categories; small (1 ${ }^{\text {st }}$ and $2^{\text {nd }}$ instars), medium ( $3^{\text {rd }}$ and $4^{\text {th }}$ instars) and large ( $5^{\text {th }}$ instar). The total number of stem borer larvae collected was used to estimate larval densities in respective plots. Collected larvae were placed individually in glass vials $(2.5 \mathrm{~cm}$ diameter $\times 7.5 \mathrm{~cm}$ depth) containing artificial diet (Onyango \& Ochieng-Odero, 1994) and plugged with cotton wool. Collected larvae together with all other stem borer life stages were taken to the laboratory at International Centre of Insect Physiology and Ecology (icipe) where they were reared at ambient temperatures of $24-25^{\circ} \mathrm{C}$ and a relative humidity of $55-65 \%$, with a 12:12 light: dark photoperiod until pupation. Resulting pupae were placed individually in plastic jars lined at the bottom with moist paper towel while the remaining larvae were maintained in vials with artificial diet. Humidity in plastic jars was maintained by moistening paper towels using a few drops of distilled water once after every 2 days. Vials were inspected each day for parasitoid cocoon spinning and pupation, while pupae jars were inspected for adult moth emergence. Emerging parasitoids were identified and recorded while moths were used to confirm stem borer species identity. Parasitism (\%) was estimated from the number of stem borer larvae that gave cocoons from the appropriate larval stage and expressed as the proportion of respective plot densities. At the end of the

\section{RESULTS}

Stem borer diversity, infestation and mean larval density: Chilo partellus was the only stem borer species found occurring in the fields during this study. Stem borer infestation varied among treatments $(A, B$ and $C)\left(F_{2,9}=5.835 ; p<0.05 ;\right.$ Table 2). Infestation in study, dry maize cobs were harvested and their respective weights recorded.

Estimating effect of infestation and parasitism on maize yield: The effect of infestation and parasitism on maize yield was estimated using a hypothetical approach (Songa et al., 2001). In this approach, ten infested and non-infested maize plants were identified and tagged in all the farmers' experimental fields. The following parameters were recorded from the tagged plants during harvest: height and diameter, tunnelling length, number of exit holes, number of cocoon cases and maize cob weights with husks. These parameters were statistically compared to determine their respective effects on observed yields.

Statistical analyses: Data on the percentage infestation, larval density, stem borer parasitism and cob weight (with husk) from individual fields, were pooled in respective treatments and used as replicates during analysis. Before analysis, the aforementioned parameters were tested for normality using ShapiroWilk's test. Percentage infestation, larval density and yield were normally distributed and One-way ANOVA was thus used to compare variations among treatments. Tukey's post-hoc test was used to separate means where treatments were found to be significantly different $(p<0.05)$. Percentage parasitism was log transformed $\left(\log _{10} x+1\right)$ before subjection to Oneway ANOVA and means separated using Tukey's posthoc test. Number of exit holes, tunnelling length, plant height and stem diameter were analysed to test their respective effects on cob weight. Plant height, stem diameter, number of nodes and yield from non-infested and infested plants were compared using MannWhitney test. Yield data was standardized to yield per acre in order to correct for differences in farm sizes. Mean yield between infested and non-infested plants were compared using student's $t$-test while Pearson's correlation test was used to determine the effect of tunnel length, exit holes and cocoon cases on maize yield. GLM was used to determine the effect of plant height, stem diameter, mean larval density, infestation and parasitism on maize yield.

treatment $\mathrm{A}(0.5 \pm 0.3 \%)$ was significantly lower compared to treatment $B(2.0 \pm 0.2 \%)$ and $C(1.5 \pm$ $0.4 \%$ ). Like infestation levels, there was evidence of variation in mean larval density among treatments $\left(F_{2,9}=8.887 ; \quad p<0.05 ;\right.$ Table 2$)$. Larval density was 
significantly lower in Treatment $A(0.5 \pm 0.4)$ compared to Treatment $B$ and $C$ where densities were $2.4 \pm 0.4$ and $2.7 \pm 0.4$ respectively (Table 2 ).

Parasitoid species composition and pest parasitism: A total of 118 cocoon masses were recovered from parasitized stem borers during the study. Cotesia flavipes was the only parasitoid species recovered and thus constituted $100 \%$ of parasitoid community. However, there was evidence of variation in level of parasitism among treatments $\left(F_{2,9}=91.97\right.$; $p<0.0001)$. Parasitism was significantly high in treatment $C(23.5 \pm 6.8 \%)$ compared to Treatment $A$ $(00.00 \pm 0.00)$ and $B(0.3 \pm 0.1)$ where populations of stem borers and parasitoids were manipulated respectively (Table 2).

Table 2: Mean $(\bar{x} \pm S E)$ stem borer infestation, larval density, parasitism and maize yield among different insecticide treatments

\begin{tabular}{l|l|l|c|c}
\hline Treatment & Infestation (\%) & Larval density & Parasitism (\%) & Yield (kg/acre) \\
\hline $\mathrm{A}$ & $0.5 \pm 0.3^{\mathrm{a}}$ & $0.5 \pm 0.4^{\mathrm{a}}$ & $0.0 \pm 0.0^{\mathrm{a}}$ & $915.3 \pm 294.2^{\mathrm{a}}$ \\
$\mathrm{B}$ & $2.0 \pm 0.2^{\mathrm{b}}$ & $2.4 \pm 0.4^{\mathrm{b}}$ & $0.3 \pm 0.1^{\mathrm{a}}$ & $841.3 \pm 223.9^{\mathrm{a}}$ \\
$\mathrm{C}$ & $1.5 \pm 0.4^{\mathrm{ab}}$ & $2.7 \pm 0.4^{\mathrm{b}}$ & $23.5 \pm 6.8^{\mathrm{b}}$ & $587.0 \pm 047.7^{\mathrm{a}}$ \\
\hline$F_{2,9}$ & 5.835 & 8.887 & 91.97 & 0.641 \\
$p$-value & $<0.05$ & $<0.01$ & $<0.0001$ & $>0.05$ \\
\hline
\end{tabular}

Mean $(\bar{x} \pm S E)$ within columns followed by the same lower case superscripts are not significantly different $(p>0.05)$ (Tukey's post hoc test).

Maize yield: After correcting for difference in farm sizes, Treatment A produced relatively higher yield $(915.3 \pm 294.2 \mathrm{~kg} / \mathrm{acre})$ followed by Treatment B $(841.3 \pm 223.9 \mathrm{~kg} / \mathrm{acre})$ and Treatment $\mathrm{C}$ (587.0 $\pm 47.7 \mathrm{~kg} / \mathrm{acre})$. However, statistical comparison did not reveal any differences in mean yield among the treatments $\left(F_{2,9}=0.64 ; p>0.05\right)$ (Table 3$)$.

i). Effects of plant diameter, plant height and number of nodes on maize yield

Comparison of infested and non-infested maize plants: On average, infested maize plants were significantly shorter $(171.6 \pm 4.3 \mathrm{~cm})$ compared to non- infested plants $(202.6 \pm 3.5 \mathrm{~cm}) \quad(W=4033 ; \quad p<0.05)$ (Table 3). Significant variations were also observed in the number of nodes between infested $(10.4 \pm 0.2)$ and non-infested plants $\quad(11.3 \pm 0.2) \quad(W=4814.5$; $p<0.05)$. However, plant diameter did not vary between infested $(2.1 \pm 0.0)$ and non-infested plants $(2.1 \pm 0.0)$ $(W=6003 ; p>0.05)$ (Table 3). Statistical comparison of yield weights revealed significant variation between infested $(100.9 \pm 8.1)$ and non-infested plants $(199.1 \pm 6.4)(W=2579.5 ; p<0.05)$.

Table 3: Mean $(\bar{x} \pm S E)$ plant height, number of nodes, diameter and yield weight of infested and non-infested plants.

\begin{tabular}{l|l|l|l|l}
\hline Infestation status & Plant height(cm) & Number of nodes & Plant diameter $(\mathbf{c m})$ & Yield weight(Kg) \\
\hline Infested plants & $171.6 \pm 4.3^{\mathrm{a}}$ & $10.4 \pm 0.2^{\mathrm{a}}$ & $2.1 \pm 0.1^{\mathrm{a}}$ & $100.849 \pm 8.1^{\mathrm{a}}$ \\
Non-infested plants & $202.6 \pm 3.5^{\mathrm{b}}$ & $11.3 \pm 0.2^{\mathrm{b}}$ & $2.1 \pm 0.0^{\mathrm{a}}$ & $199.056 \pm 6.4^{\mathrm{b}}$ \\
\hline$W$ value & 4033 & 4814 & 6003 & 2579.5 \\
$p$-value & $<0.001$ & $<0.001$ & $>0.05$ & $<0.001$ \\
\hline
\end{tabular}

Mean $( \pm S E)$ within columns followed by the same lower case superscripts are not significantly different $(p>0.05)$

ii) Effect of infestation and parasitism on cob weights: Regardless of the status of infestation, GLM analysis revealed that performance of maize plant is positively affected by maize plant height $(b=0.51$; $t=4.20 ; \quad p<0.0001)$ and diameter $(b=48.15 ; \quad t=4.01$; $p<0.0001)$. Further GLM analysis of stem borer infestation parameters (tunnelling length and exit holes) revealed their respective negative effect on cob weights (Table 4). Tunnelling length caused during stem borer feeding negatively affected cob weights $(b=1.65$; $t=-$ $3,524.01 ; p<0.05)$. The number of exit holes indicating number of stem borers that completed their life cycle within the maize stems, also negatively affected cob weight though insignificantly $(b=-7.08 ; t=-1.86 ; p>0.05)$ 
(Table 4). The number of cocoon cases did not have a $\quad p>0.05)$. significant effect on cob weight $(b=-4.34 ; t=-0.49$;

Table 4: Estimated effect of different growth, infestation and parasitism parameters on cob weights

\begin{tabular}{l|l|l|l|l}
\hline Term & $\mathbf{b}$ & SE & $\mathbf{T}$ & $\mathbf{p}(\mathbf{T})$ \\
\hline (Intercept) & -47.209 & 24.558 & -1.92 & 0.05582 \\
Height of maize plant (cm) & 0.510 & 0.121 & 4.20 & 0.00004 \\
Maize plant diameter (cm) & 48.154 & 11.997 & 4.01 & 0.00008 \\
Tunnelling length (cm) & -1.650 & 0.469 & -3.52 & 0.00052 \\
Number of exit holes & -7.083 & 3.800 & -1.86 & 0.06362 \\
Number of cocoon cases & -4.338 & 8.936 & -0.49 & 0.62783 \\
\hline
\end{tabular}

\section{DISCUSSION}

Chilo partellus was the only stem borer pest collected during the study contrary to results from previous surveys in which $B$. fusca reportedly dominated the stem borer community (Seshu Reddy, 1983; Ongámo et al., 2006a, b). The predominance of $C$. partellus had previously been reported in low altitude areas (Nye, 1960; van Hamburg, 1979; Seshu Reddy, 1983), an observation attributable to its competitive advantage over indigenous stem borer species. However, with climate change, predictive models showed that $C$. partellus was likely to expand its distribution range beyond low altitude areas (Khadioli et al., 2014; Mwalusepo et al., 2015). Recovery of C. partellus from mid-altitude zone during this study validated the predictive models. Other researchers have reported similar range expansion by $C$. partellus into mid and high -altitude areas (Kfir, 1997; Kfir et al., 2002b; Songa, 1999; Overholt et al., 2000). Found associated with C. partellus, was its old association parasitoid, $C$. flavipes whose establishment is hereby confirmed in moist mid-altitude zones despite there being no official release (Omwega et al., 1995). Its presence is attributed to a population of parasitoids which escaped from a laboratory at icipe, Mbita point field station where they had been quarantined for pre-release studies (Omwega et al., 1995). Cotesia flavipes was the only parasitoid recovered contrary to earlier surveys during which the native, gregarious larval endoparasitoid Cotesia sesamiae Cameron was also recovered (Zhou and Overholt, 2001). The direct effect of stem borer infestation on maize production and contribution of biological control agents have rarely been quantified with two documented studies having been done on small plots (Kfir et al., 2002b; Cugala et al., 2006). The high cost involved in replicating experiments using larger plots was cited as a constraint and thus plots measuring $333 \mathrm{~m}^{2}$ in South Africa (Kfir et al., 2002a) and $100 \mathrm{~m}^{2}$ in Mozambique (Cugala et al.,
2006) were used, 10 years after the initial release of $C$. flavipes in the latter. However, small plots have been found to be ineffective in determining the effect of natural enemies on pests because results are blurred by movement of natural enemies across plots (van Driesche and Bellows, 1996). Larger plots measuring between 720 to $4820 \mathrm{~m}^{2}$ were used in this study after 23 years since the initial release of $C$. flavipes in Kenya in order to overcome this challenge. Following the study, generated results provided evidence on the impact of C. partellus infestation on maize yield and contribution of C. flavipes in limiting losses associated with infestations. Low infestation observed in Thunder treated fields were attributed to mortality induced by the insecticide which killed majority of first instar larvae with only a few that had penetrated into stems surviving. The higher percentage infestation recorded in treatment $B$ was as a result of partial removal of natural enemies by dimethoate application, an observation that corroborated findings from South Africa and Mozambique (Kfir, 2002b; Cugala et al., 2006). In South Africa, direct effects of natural enemies on $B$. fusca and C. partellus populations were assessed and significantly higher infestation was recorded in plots sprayed with dimethoate with higher parasitism being recorded in unsprayed plots (Kfir, 2002b). In Mozambique, a similar experiment was carried out on C. partellus, B. fusca and S. calamistis and similar results were obtained following natural enemy exclusion (Cugala et al., 2006). In treatment B, parasitoid action was considerably reduced by dimethoate application. However, $100 \%$ elimination of natural enemies is often not achieved by insecticide application (Kidd and Jervies, 2005) and this explained the low parasitism rate in treatment $B$ in comparison to treatment $C$. This is in agreement with results obtained from a similar study carried out by Cugala et al. (2006) where parasitism in control plots were higher than in stem 
borer and parasitoid-excluded fields. This study revealed a general trend in increase of parasitism in the region. In 1997, Khan et al. (1997) recorded about 3.5\% parasitism while Ogeda recorded about $6.1 \%$ in 1999 (Ogeda, 1999). Results of this study demonstrate an increase in parasitism (23\%) in control fields. Contrary to variations in stem borer pest infestation and parasitism among treatments, there was no evidence of variation in maize yield among treatments. This contradicted earlier reports that natural enemies (including C. flavipes) played a considerable role in stem borer population suppression resulting in increased maize yield (Cugala et al., 2006). It is worth noting that maize yield is affected by both biotic and abiotic factors. Manipulated stem borer and parasitoid populations are only part of the biotic factors that may affect yield. However, comparison of yields from infested and non-infested plants showed that infestation contributes to yield loss depending on the health of the plant. Plant height and diameter played an important role towards yield as they together showed positive influence. In contrast, infestation parameters particularly tunnel length and number of exit holes negatively affected the yield. Tunnel length is considered a good indicator of stem borer damage as it results in destruction of the meristematic tissue (Polaszek, 1998; Cherry et al., 1999; Midega, 2013) leading to stem weakening and lodging (Santiago et al., 2003). The observed low yield in infested plants was thus attributed to stem tunnelling which interfered with translocation of water and nutrients to actively photosynthesizing parts of a plant resulting in reduced plant growth, seed setting and grain sizes (Kalule et al., 1997; Polaszek 1998; Malvar et al, 2008) thus reduced yield (Ajala and Saxena, 1994; Songa et al., 2001; Midega, 2013). The other infestation parameter, number of exit holes, showed a strong positive correlation to tunnelling length indicating that with an increase in the number of stem borers that completed

\section{ACKNOWLEDGEMENT}

The authors wish to acknowledge local farmers in Oluch Village, Homa-Bay County, Kenya, for their involvement in the execution and management of

\section{REFERENCES}

Ajala, S. O and Saxena, K. (1994). Interrelationship among Chilo partellus (Swinhoe) Damage parameters and their contribution to grain yield reduction in maize Zea mays L. Applied Entomology and Zoology 29: 469-476. their life cycle within the maize stem, there was an associated increase in crop damage.

Cocoon cases are an indication of parasitoid presence and action on the target pest. Parasitism being a numerical response, an increase in number of exit holes and tunnelling lengths was observed to be accompanied by an increase in cocoon cases. However, larval parasitoids attack $3^{\text {rd }}, 4^{\text {th }}$ or $5^{\text {th }}$ instar larvae of the pest after damage had been done on maize. Results obtained in this study upheld reports that the number of stem borers, exit holes and tunnelling length are the most important factors affecting yield in maize crop (Songa et al., 2001). According to the same author, these were then followed by plant height and plant diameter in that order of importance. Generally, this study revealed a reduction in stem borer infestation levels in the area $1.45 \%$ in control fields) compared to earlier studies in which stem borer infestation levels were estimated at $8-100 \%$ (Seshu Reddy et al., 1983) and 33.72\% (Ongámo et al., 2006a). Reduced infestation levels were attributed to increase in parasitism by $C$. flavipes. These results demonstrate that International Centre of Insect Physiology and Ecology's Biological Control programme which initiated the importation and release of $C$. flavipes succeeded in the objective to reduce stem borer population in the study area. This biological control success story can thus be replicated in other areas within and beyond the nation's borders where a similar pest problem may occur. However, given the modus operandi of the parasitoid, decreased infestation coupled with increased parasitism did not translate into improved maize yield. Optimum yield may be realised when biological control involving both egg and larval parasitoids are used. Further research to identify egg parasitoids of $C$. partellus in the pest's native range or that have expanded their host range to include $C$. partellus in Kenya needs to be done.

experimental fields. We would also wish to thank the Department for International Development (DFID) for the financial support.

Cherry, A. J., Lomer, C. J., Djegui, D and Schulthess, F. (1999). Pathogen incidence and their potential as microbial control agents in IPM of maize stem borers in West Africa. Biocontrol 44: 301-327. 
CIBC (1968-1972). Reports of the work carried out. Commonwealth Institute of Biological Control. London.

Cugala, D., Schulthess, F., Ogol, C. P. K and Omwega, C. O. (2006). Assessment of the impact of natural enemies on stem borer infestations and yield loss in maize using selected insecticides in Mozambique, Annales de la Société Entomologique de France 42: 503510.

Debach, P. (1946). An insecticidal check method for measuring the efficacy of entomophagous insects. Journal of Economic Entomology 39: 695-697.

Debach, P and Rosen, D. (1991). Biological control by natural enemies, 2nd edn. Cambridge University Press, Cambridge, UK.

Fukuto, T. R. (1990). Mechanism of action of organophosphorus and carbamate insecticides. Environmental Health Perspectives 87: 245-254.

Greathead, D. J. (1990). Utilization of natural enemies of Chilo spp for management in Africa. Insect Science and its Application 11: 749-755.

Gullan, P. J and Cranston, P. S. (2005). The insects: An outline of Entomology. Malden: Blackwell Publishing.

Jiang, N., Zhou, G., Overholt, W. A., Muchugu, E and Schulthess, F. (2006). The temporal correlation and spatial synchrony in the stemborer and parasitoid system of Coast Kenya with climate effects. Annales de la Société Entomologique de France 42: 381387.

Jones, D. (1982). Predators and parasites of temporary row crop pests: agents of irreplacable mortality or scavengers acting prior to other mortality factors? Entomophaga 27: 245-265.

Kalule, T., Ogenga-Latigo, M.W and Okoth, V. A. (1997). Seasonal fluctuations and damage of lepidopteran stem borers of maize in a major agroecozone of Uganda. African Crop Science Journal 5: 385-393.

Kenmore, P. E., Carino, F., Perez, C., Dyck, V and Gutierrez, A. P. (1984). Population regulation of the rice brown plant hopper Niloparvata lugens Stal within rice fields in the Philippines. Journal of Plant Protection 1: 19-37.

Kidd, N. A. C and Jervis, M. A. (2005). Population dynamics. Insects as natural enemies (ed.by
MA Jervis) Cardiff, Wales, United Kingdom. pp. 435-523.

Kfir, R. (1994). Attempts at the biological control of the stem borer Chilo partellus Swinhoe Lepidoptera: Pyralidae in South Africa. African Entomology 2: 67-68.

Kfir, R. (1997). Natural control of the cereal stemborers Busseola fusca and Chilo partellus in South Africa. Insect Science and its Application 17: 61-68.

Kfir, R. (2002a). Increase in cereal stem borer populations through partial elimination of natural enemies. Entomologia Experimentalis et Applicata 104: 299-306.

Kfir, R., Overholt, W. A., Khan, Z. R and Polaszek, A. (2002b). Biology and management of economically important lepidopteran cereal stem borers in Africa. Annual review of Entomology, 4:701-31.

Kfir, R. (2004). Effect of parasitoid elimination on populations of diamondback moth in cabbage. In Proceedings of the 4th international workshop, Melbourne, Australia pp. 197-205.

Khadioli, N., Tonnang, Z. E. H., Muchugu, E., Ong'amo, G., Achia, T., Kipchirchir, I., Kroschel, J and Bruno, L. R. (2014). Effect of temperature on the phenology of Chilo partellus Swinhoe Lepidoptera, Crambidae; simulation and visualization of the potential future distribution of C. partellus in Africa under warmer temperatures through the development of lifetable parameters. Bulletin of Entomological Research 104: 809-22.

Khan, Z. R., Ampong-Nyarko, K., Chilishwa, P., Hassanali, A., Kimani, S., Lwande, W., Overholt, W. A., Pickett, J. A., Smart, L. A., Wadhams, L. J and Woodcock, C.M. (1997). Intercropping increases parasitism of pests. Nature 388: 631-632.

Kipkoech, A. K., Schulthess, F., Yabann, W.K., Maritim, H.K., Muchugu, E and Mithofer, D. (2009). The economic value of releasing parasitoid for the control of maize stem borers in East and Southern Africa. In International Association of Agricultural Economics Conference, Beijing, China pp. 1-20.

Luck, R.F., Shepard, B. M and Kenmore, P. E. (1999). Evaluation of biological control with experimental methods. Handbook of biological control principles and application of biological 
control (ed by TS Bellow \& Fisher TW), Academic press, San Diego. pp. 225-242.

Malvar, R., Butrón, A., Ordas, B and Santiago, R. (2008). Causes of Natural Resistance to Stem Borers in Maize. Crop Protection Research Advances 313.

Midega, C. A. (2013). Determining the effect of stemborers on yields of cereal crops, principally maize and sorghum. icipe 254 .

Mohyuddin, A.I. (1991). Utilizat.ion of natural enemies for control of insect pests of sugarcane. Insect Science and its Application 12: 19-26

Mwalusepo, S., Tonnang, H. E. Z., Massawe, E. S., Okuku, G.O., Khadioli, N., Johansson, T., Calatayud, P-A and Bruno, L. R. (2015). Predicting the impact of temperature change on the future distribution of maize stem borers and their natural enemies along East African mountain gradients using phenology models. PLOS ONE 10: 1-23.

Nye, I. W. B. (1960). The insect pests of graminaceous crops in East Africa. Colonial research study No. 31. London; Her Majesty's Stationary Office, pp. 48.

Ogeda, K. O. (1999). Evaluation of the impact of Cotesia flavipes Cameron Hymenoptera: Braconidae and indigenous parasitoids on stem borer populations in South Western Kenya. MSc thesis, Kenyatta University, Kenya.

Omwega, C. O., Kimani, S. W., Overholt, W. A and Ogol, C. K. P. O. (1995). Evidence of the establishment of Cotesia flavipes Hymenoptera: Braconidae in continental Africa. Bulletin of Entomological Research 85: 525-530.

Ong'amo, G. O., Bruno, L. R., Dupas, S., Moyal, P., Calatayud, P-A and Silvain, J-F. (2006a). Distribution, pest status and agro-climatic preferences of lepidopteran stem borers of maize in Kenya. Annales de la Société Entomologique de France 42: 171-177.

Ong'amo, G. O., Bruno, L. R., Dupas, S., Moyal, P., Muchugu, E., Calatayud, P-A and Silvain, J-F. (2006b). The role of wild host plants in the abundance of lepidopteran stem borers along altitudinal gradient in Kenya. Annales de la Société Entomologique de France 42: 363370.

Onyango, F. O and Ochieng'-Odero, J. P. R. (1994). Continuous rearing of the maize stem borer
Busseola fusca on an artificial diet. Entomologia Experimentalis et Applicata 73: 139-144.

Overholt, W. A., Kimani, S. K., Mbapila, J., Lammers, P and Kioko, E. (1994). Ecological considerations of the introduction of Cotesia flavipes Cameron Hymenoptera: Braconidae for biological control of Chilo partellus Swinhoe Lepidoptera: Pyralidae in Africa. Biocontrol News and Information 15: 19N-24N.

Overholt, W. A., Ngi-Song, A. J., Omwega, C. O., Kimani-Njogu, S. W., Mbapila, J., Sallam, M. N and Ofomata, V. (1997). A review of the introduction and establishment of Cotesia flavipes Cameron in East Africa for biological control of cereal stem borers. Insect Science and its Application 17: 79-88.

Overholt, W. A., Songa, J. M., Ofomata, V and Jeske, R. (2000). The spread and ecological consequences of the invasion of Chilo partellus (Swinhoe) (Lepidoptera: Crambidae) in Africa. Invasive species in Eastern Africa (ed. by. EE Lyons \& SE Miller) Proceedings of a workshop held at icipe, 5-6 July 1999. icipe science press Nairobi, Kenya. pp. 52-58.

Polaszek, A. (1998). African cereal stem borers: Economic importance, Taxonomy, Natural enemies and Control. $C A B$ International in association with the ACP-EU Technical Centre for Agricultural and Rural Co-operation CTA. pp. 530.

Rodriguez, M. A and Hawkins, B. A. (2000). Diversity, function and stability in parasitoid communities. Ecology Letters 3: 35-40.

Sanda, N. B and Sunusi, M. (2014). Fundamentals of biological control of pests. International Journal of Clinical \& Biological Sciences 1: 111.

Santiago, R., Souto, X. C., Sotelo, J., Butrón, J and Malvar, R. A. (2003). Relationship between maize stem structural characteristics and resistance to pink stem borer Lepidoptera: Noctuidae attack. Journal of Economic Entomology 96: 1563-1570.

Seshu Reddy, K. (1983). Studies on the stem-borer complex of sorghum in Kenya. Insect Science and its Application 4: 3-10.

Seshu Reddy, K. V and Walker, T. T. (1990). A review of the yield losses in graminaceous crops caused by Chilo spp. Insect Science and its Application 11: 563-569. 
Songa, J. M. (1999). Distribution, importance and management of stem borers Lepidoptera in maize production systems of semi-arid Eastern Kenya with emphasis on biological control. PhD dissertation, Kenyatta University, Nairobi, Kenya.

Songa, J. M., Guofa, Z and Overholt, W. A. (2001). Relationships of stemborer damage and plant physical conditions to maize yield in a semiarid zone of Eastern Kenya. Insect Science and its Application, 21: 243-249.

Tams, W. H. T. (1932). New species of African Heterocera. Entomologist 65: 1241-1249

Van Driesche, R. G and Bellows, J. R. T. S. (1996) Biological Control. Chapman and Hall, New York.

Van Hamburg, H. (1979). The grain sorghum stalk borer, Chilo partellus Swinhoe Lepidoptera: Pyralidae. Seasonal changes in adult populations in grain sorghum in the Transvaal. Journal of Entomological Society South Africa 42: $1-9$.

Zhou, G and Overholt, A. (2001). Spatial-Temporal Population Dynamics of Cotesia flavipes (Hymenoptera: Braconidae) in Kenya. Environmental Entomology 30: 869-876.

Zhou, G., Baumgartner, J and Overholt, W. A. (2001). Impact assessment of an exotic parasitoid on stemborer Lepidoptera population dynamics in Kenya. Ecology Applied 11: 1554-1562. 